Article

\title{
Sustainability Literacy in a Time of Socio-Ecological Crisis: Using Reaccreditation as a Leverage Point for Innovation in Higher Education
}

\author{
Todd LeVasseur ${ }^{1, *}$ and Christopher Ciarcia ${ }^{2, *}$ \\ 1 Environmental and Sustainability Studies Program, College of Charleston; Charleston, SC 29424, USA \\ 2 Office of Student Organizations and Activities, University of Kentucky; Lexington, KY 40506, USA \\ * Correspondence: levasseurtj@cofc.edu (T.L.); ciarciac@uky.edu (C.C.)
}

Received: 28 June 2019; Accepted: 28 August 2019; Published: 18 September 2019

\begin{abstract}
This article presents a case study of innovation in sustainability education in higher education. It does so by explaining the to-date progress of a multi-year reaccreditation process begun in 2016 for the College of Charleston (CofC), a public liberal arts and sciences university in Charleston, South Carolina of approximately 10,000 undergraduates and 1300 graduate students. The question addressed is how can a higher education institute strategically embed sustainability literacy that is focused on social/environmental engagement, in a way that contributes to measurable student learning gains? We argue that the leverage point of institutional reaccreditation provides a strategic entryway into embedding such sustainability across curricular and co-curricular settings in innovative capacities. We do so by discussing how sustainability education was implemented into a co-curricular civic engagement program, alternative break, to build students' sustainability literacy at the College of Charleston. The article concludes by reflecting on lessons learned at CofC on how to use institutional reaccreditation as a driver of sustainability education through civic engagement in an era of socio-ecological collapse.
\end{abstract}

Keywords: sustainability literacy; reaccreditation; assessment; civic engagement; innovation; alternative break

\section{Introduction}

This article presents a case study of innovation in educating for sustainability in higher education. It does so by explaining the to-date progress of a multi-year reaccreditation process begun in 2016 for the College of Charleston (CofC), a public liberal arts and sciences university in Charleston, South Carolina of approximately 10,000 undergraduates and 1300 graduate students [1]. We argue that the leverage point of institutional reaccreditation provides a strategic entryway into embedding sustainability across curricular and co-curricular settings in innovative capacities. We further argue that reaccreditation can contribute to creating new collaborative partnerships that allow for education on social/ecological interfaces.

We begin by discussing CofC's reaccreditation process and how this led to a project focused on embedding sustainability literacy across the entirety of the undergraduate student body. We then focus on a key aspect of the project: place-based learning as a mechanism for fostering civic engagement at the interface of social, environmental, and economic systems. This section includes a discussion about program development and use of assessment results and how strategically partnering civic engagement with sustainability goals can help invite students to participate in social change. The article concludes by reflecting on lessons learned at CofC on how to use institutional reaccreditation as a driver of sustainability education in an era of socio-ecological collapse. 
Before proceeding it should be noted that co-author LeVasseur was first interim director and then since 2016 has been permanent director of the core aspect of the reaccreditation process shared in this article. He therefore directs the implementation of both the Quality Enhancement Plan (QEP) itself, and directs its institutional home, the Sustainability Literacy Institute (SLI). Co-author Ciarcia was, until January 2019, the associate director of the Center for Civic Engagement at the College of Charleston. In this role, he served on the QEP's curricular/co-curricular subcommittee, the QEP's assessment team, and directed and assessed the alternative break partnership afforded by the QEP between the Center for Civic Engagement and SLI. These roles have afforded a level of familiarity with CofC's efforts to embed sustainability literacy, but also limit the author's perspectives to this specific context of sustainability in higher education, as successful implementation of the QEP has been the guiding professional focus of co-author LeVasseur for the past three years.

\section{Can Reaccreditation Be a Platform for Innovation in the Teaching of Sustainability?}

The accreditation process can be perceived as onerous and may provide an occasion for institutional stress, especially for those in charge of a campus' accreditation process. However, this process provides timely opportunities to redesign key aspects of the curricula and an institute's overall administrative capacities [2]. This can also hold true for sustainability in higher education, where assessment of sustainability goals are at times lacking coherent structure [3]; but where campus-wide opportunities for structural innovations, as with reaccreditation, allow for the opportunity to strategically embed sustainability competencies in new and exciting ways [4]. Because reaccreditation is a requirement, this process provides a direct leverage point for redesigning curricular and co-curricular offerings so that they include sustainability competencies. Strategically inserting sustainability literacy, skills, and proficiencies into various levels of a higher education institute (for curricula: at the school level, program level, and/or departmental level) is made possible by institutional reaccreditation, and this opportunity was captured by CofC.

CofC's reaccreditation format and process is catalyzed by standards put forth by The Southern Association of Colleges and Schools Commission on Colleges (SACSCOC), of which CofC is a member. SACSCOC is a regional accreditor that accredits most of the colleges and universities in 11 Southern states in the United Sates, including Alabama, Florida, Georgia, Kentucky, Louisiana, Mississippi, North Carolina, South Carolina, Tennessee, Texas, and Virginia. In addition, SACSCOC accredits a few schools in Latin America. The regional accreditor is a membership-based organization that consists of 793 members. SACSCOC publishes over 70 standards in the Principles of Accreditation that an institute is required to be in compliance with to maintain their accreditation [5]. SACSCOC's accreditation processes consist of a 10-year cycle that includes a five-year interim report. Two standards within the principles relate to a Quality Enhancement Plan (QEP). These are [6]:

(1) Core Requirement (CR) 2.12: The institution has developed an accepted QEP that includes an institutional process for identifying key issues emerging from institutional assessment and focuses on learning outcomes and/or the environment supporting student learning and accomplishing the mission of the institution.

(2) Comprehensive Standard (CS) 3.3.2: The institution has developed a QEP that (1) demonstrates institutional capacity for the initiation, implementation, and completion of the QEP; (2) includes broad-based involvement of institutional constituencies in the development and proposed implementation of the QEP; and (3) identifies goals and a plan to assess their achievement.

It is within this context that in 2015 CofC solicited proposals from faculty and staff for CofC's next QEP, set to officially begin in academic year 2017-2018. The campus call for proposals solicited six possible QEP topics. A Reaffirmation Leadership Team, which included the President, Executive Vice President of Academic Affairs/Provost, Executive Vice President of Business Affairs, Speaker of the Faculty, and SACSOC liaison, amongst others, evaluated these six submissions. The Reaffirmation Leadership Team decided that the merits of what became CofC's current QEP justified selection, and in 
Fall 2015, the Reaffirmation Leadership Team officially selected "Sustainability Literacy as a Bridge to Addressing twenty-first Century Problems" as CofC's next QEP.

Of the six submissions for CofC's next QEP, this proposal was the only one that included sustainability in higher education goals and the strategies to embed sustainability literacy across the curricula. The initial proposal was submitted by the director of the College's Office of Sustainability (OoS), who was the original QEP interim director until a campus-wide search was undertaken for a permanent QEP director, which co-author LeVasseur received. The OoS oversees sustainability in relation to campus operations, facilities, and applied internships related to these at the College, but as an organizational entity was not heavily involved in curricular and co-curricular interventions related to sustainability. This gap in sustainability at the College was recognized by the Reaffirmation Leadership Team, whose members saw the value in the vision for campus-wide sustainability literacy as outlined in the QEP proposal from the OoS director.

QEP proposals must "enhance" existing student learning, and the justification of creating a QEP project depends on analyzing various internal data points that relate to the proposed topic. These data points utilize, for example, National Survey of Student Engagement (NSSE) data; or internal reporting on student success related to programmatic student learning objectives, which at CofC are reported to the Office for Institutional Effectiveness and Strategic Planning; or how a QEP may fit into an existing strategic plan or campus mission. The Reaffirmation Leadership Team tasked with picking the reaccreditation QEP topic at CofC evaluated institutional need data points provided in the six proposals, and the vision of a new SLI that would meet the gaps in student learning identified in that proposal was deemed the strongest. The Reaffirmation Leadership Team found that the overall value of a new Sustainability Literacy Institute and its ability to help recruit and retain students in a context of social-ecological changes ("twenty-first century problems" related to the triple bottom line, like global warming, biodiversity loss, increasing student debt, helping graduates navigate a competitive globalized workforce, and institutional racism and sexism, were some data points shared in the proposal) was the strongest proposal to receive the institutional resources required to invest in a new QEP. It was believed that these resources were best spent on building a campus-wide culture of sustainability literacy that could help meet the SACSCOC mandated goals of a QEP project, while providing CofC students with holistic, interdisciplinary systems thinking and creative problem-solving skills that would equip them to better understand social, environmental, and economic problems of the twenty-first century.

\section{Institutional Context for Innovation in Sustainability Literacy}

Institutional data suggested that CofC students were lacking in key sustainability literacy competencies that its QEP is designed to address, which is consistent with CR 2.12 (as described above: "The institution has developed an accepted QEP that includes an institutional process for identifying key issues emerging from institutional assessment and focuses on learning outcomes and/or the environment supporting student learning and accomplishing the mission of the institution."). Internal auditing found that CofC students, and especially undergraduates, lacked knowledge and skills related to interdisciplinary thinking, creative problem solving, synthesis of knowledge across disciplines, and analytical reasoning. Well, quite a few readers may say that this is a snapshot of higher education deficiencies! This is where the innovation of CofC's QEP emerges: the specific context of these skills and knowledge gaps, which is sustainability. In short, CofC's QEP is an innovative attempt to redesign the higher education experience so students can understand why humans are in socio-ecological collapse, and what skills and knowledge they can gain at CofC to help mitigate or adapt to such collapse. The educational experience the QEP aims to deliver is specifically tethered to and analyzed within the context of the triple bottom line of sustainability. This campus-wide project, therefore, aims to make central to a CofC education the literacy in sustainability that CofC students currently lack, but that is needed, in order to understand social, environmental, and economic (triple bottom line/TBL) systems and how they interact to both cause and solve twenty-first century 
problems. CofC students are specifically lacking in both recognizing and understanding the TBL as an interdisciplinary exercise that requires a synthesis of knowledge across disciplines, and where systems thinking and interdisciplinary knowledge can and must be put towards solving the wicked problems of the twenty-first century.

This topic-sustainability literacy as a bridge to addressing twenty-first century problems-is innovative for CofC given the institutional need and fit of the project. It fits the mission of the College [7], which is to help students become responsible, productive members of society. It also fits into the College's Strategic Plan, which contains goals related to experiential learning; providing interdisciplinary and global perspectives, especially as these relate to understanding social, economic, environmental, ethical, scientific, and political issues of the twenty-first century; and educating the whole person through integrating curricular and co-curricular activities (more on this, below) [8]. Lastly, sustainability literacy fits with the College's Core Purpose, and also one of its Guiding Values, the latter which is fostering innovative academic programs related to the history, culture, and environment of the Lowcountry (the geographic region within which the College is located).

\subsection{Sustainability Literacy}

CS 3.3.2 (as shared above: “The institution has developed a QEP that (1) demonstrates institutional capacity for the initiation, implementation, and completion of the QEP; (2) includes broad-based involvement of institutional constituencies in the development and proposed implementation of the QEP; and (3) identifies goals and a plan to assess their achievement.") requires that the QEP be designed through broad-based campus collaboration and have an institutional support structure that is both physical and financial. The College took advantage of these requirements and established six subcommittees (including a Student Advisory Subcommittee) and an Implementation Committee that all met from every two weeks to once a month over a 16-month period to create the QEP. Over 60 faculty and staff from every Academic School and Division at the College were involved in creating the QEP. Their tasks included crafting operational definitions, goals, and student learning outcomes that determine the function and vision for the institutional structure of the QEP. This process allowed CofC to model the promise of sustainability in higher education: Innovating a new collaborative project aimed to solve a problem (reaccreditation) with that participatory collaboration [9] occurring across disciplinary lines. The final aspect of creating the institutional structure for the QEP was the creation of the Sustainability Literacy Institute (SLI) in July 2017, which is considered the hub for sustainability literacy for the College of Charleston and resides in CofC's Division of Academic Affairs under its Provost [10]. The SLI has a director, an administrative assistant, graduate and undergraduate student workers ("SLI student ambassadors"), and four SLI Fellows. Fellows are faculty who receive a course release a semester and small summer stipend and oversee aspects of the QEP's implementation. The Fellows include a Student Engagement fellow, an Innovation Fellow, and two Faculty Development Fellows. The SLI is also aided by an Implementation Committee, the same committee that helped finalize the QEP proposal, and a Marketing and Awareness subcommittee.

Various subcommittees worked on the above, overseen by the SLI/QEP director, with the goal of creating a structure and programs that could be successfully implemented on the CofC campus. One of the key moments that all of the committees were involved with, including the Reaffirmation Leadership Team, where the President and Provost were present at a final meeting and offered feedback, was finalizing the operational definition of sustainability that was to guide the QEP and SLI. The original proposal that became the base of the QEP had a definition, but subcommittee members were tasked with revisiting the definition and utilizing existing literature and best practices to finalize it. This practice is consistent with SACSCOC QEP requirements. Subcommittee members from the natural sciences, social sciences, education, and business used the original proposed definition and discussed over email updated wording based on literature review and review of how other universities in the US define sustainability. It was decided that a weak definition of sustainability (vs. a strong definition, where the economic bottom line is a subset of the social, which is a subset of the environmental) was most 
inclusive to the various departments and programs at CofC. This rich process resulted in the QEP Steering Committee presenting the following to the Reaffirmation Leadership Team for their approval, which was granted [11]:

(1) A definition of sustainability, which for the College is: The integration of social, economic, and environmental systems in ways that allow for individual, institutional, community, regional, and planetary resilience.

(2) A definition of sustainability literacy that builds on this, which is: Having the knowledge and skills to advocate for resilient social, economic, and environmental systems.

(3) The following learning goals and student learning outcomes (SLO) related to sustainability literacy (Table 1):

Table 1. Desired Learning Goals and Outcomes of QEP.

\begin{tabular}{|c|c|}
\hline QEP Goal & Student Learning Outcome \\
\hline 1. Build Awareness & $\begin{array}{l}\text { 1. Students can identify various elements of sustainability } \\
\text { and the relationships between them }\end{array}$ \\
\hline & $\begin{array}{l}\text { 2. Students can identify key ways to be more sustainable in } \\
\text { their personal life and on-campus. }\end{array}$ \\
\hline 2. Synthesize and Integrate Knowledge & $\begin{array}{l}\text { 3. Students will identify policies and practices that have led } \\
\text { to unsustainability. }\end{array}$ \\
\hline & $\begin{array}{l}\text { 4. Students will synthesize knowledge from two or more } \\
\text { systems to address a sustainability problem }\end{array}$ \\
\hline 3. Skill Building and Competency Learning & $\begin{array}{l}\text { 5. Students will demonstrate the impact of } \\
\text { production/consumption practices on social, economic } \\
\text { and/or ecological systems. }\end{array}$ \\
\hline 4. Experiential and Learning Practice & 6. Students will design a solution to a sustainability problem. \\
\hline 5. Change Agents for Resiliency & $\begin{array}{l}\text { 7. Students are advocates for resiliency at the individual, } \\
\text { institutional, community, national, or international level. }\end{array}$ \\
\hline
\end{tabular}

These goals and SLOs utilize the revised Bloom's taxonomy for active cognition and invite students to first become aware of sustainability literacy through the triple bottom-line concept, and then over their student career gain deeper levels of sustainability literacy. By offering sustainability focused and related courses across the curricula it is hoped that this will "cause students to have the most expanded conception of sustainability [as a] result of the way in which [these] courses are taught" [12] (p. 416) within the context of a campus-wide QEP that has a shared definition of sustainability literacy for all disciplines. The ultimate goal is that CofC students graduate as change agents for resiliency, harnessing a multidisciplinary tool bag of skills to address twenty-first century problems.

Of note for this special issue is that a few innovative curricular [13] and co-curricular practices in higher education are embedded in this QEP and derive from its goals and SLOs. A key one is curricular infusion of sustainability literacy as the QEP strategically scaffolds sustainability concepts throughout the curricula. This becomes most effective when the institution puts forth resources to train faculty and staff in pedagogical and programmatic techniques where the SLI is the home of such training and dispersal of resources. Some of the key resources offered by the SLI to faculty include offering add pay stipends for the extra assessment work required for QEP reporting and attending a May training on the TBL and how to teach and assess QEP SLOs; course releases; sustainability literacy pedagogical workshops for faculty from both on and off-campus experts; the support by chairs and deans of faculty offering sustainability focused special topics courses outside of their normal teaching responsibilities; access to the four SLI Faculty Fellows; the ability to apply for SLI mini grants that fund workshops or guest lectures for sustainability classes; and the creation and maintenance of a faculty-focused resource of web-based teaching tools. Related, the visibility of the QEP and its role in reaccreditation provides a helpful context for top-down support of and messaging for the campus on sustainability literacy. Such support helps overcome barriers to embedding sustainability on a campus [14]. 
Despite this support and this fit, the challenge of directing the SLI, the institutional home of the QEP, and the QEP's 39 assessment measures that assess its five goals and seven SLOs, is multifaceted. One challenge is its size-CofC's QEP represents a truly campus-wide project with classes taught in every department, that was created from scratch. Tracking the 39 assessment measures also requires considerable labor and is aided by an Assessment Team. The data is to be compiled over five years of implementation for a five-year interim report to SACSCOC, where the data helps CofC determine if the learning gaps that informed the selection and creation of the QEP were met, and why or why not. The data also will help CofC determine which aspects of the QEP will continue as part of its identity, and which aspects of the QEP will not carry forward after the interim report.

A key challenge to date in successfully embedding sustainability literacy across campus, at least where this is done under the auspices of reaccreditation, has been finding the most helpful balance between garnering faculty buy-in, fighting institutional bureaucratic inertia, and inviting students to understand why these twenty-first century problems are important. It is also a challenge to navigate the tension between recognizing that "A sustainability curriculum is empty if it is primarily theoretical. However, it is shallow if it lacks study, reflection, and substance" [15] (p. 164). That is to say that the product of the QEP must be based in sound theoretical knowledge, but be applicable to real world issues. For example, if students only learn about the theory of systems thinking via the TBL, but do not have experiential learning in the community that allows them to see how these systems actually interact, then students will not be able to become change agents able to find leverage points to advocate for resiliency in the face of social-economic-environmental collapse.

Of the many innovations in progress for CofC in sustainability literacy education, it is the partnership with CofC's Center for Civic Engagement that is navigating precisely this tension alluded to above by Mitchell Thomashow, where students receive both theoretical but also experiential and reflective engagement with sustainability literacy. The next section, written by co-author Ciarcia, explains the role of the Center for Civic Engagement on CofC's campus, clarifies the partnership with the SLI that has emerged within the context of CofC's QEP, and articulates how CofC is innovating social change via sustainability-themed alternative breaks.

\subsection{Civic Engagement as a Pathway to Sustainability Literacy}

Over the past several decades, civic engagement has become an integral part of institutions of higher education throughout the country. A lot of this has to do with civic engagement being classified as a high-impact practice (HIP), as it has shown to lead to student persistence, retention, academic achievement, and student involvement [16]. In addition, higher education leaders have called for a need for students to become more civically engaged upon graduating $[17,18]$. This need has become even more dire since the publication, A Crucible Moment: College Learning and Democracy's Furniture [19], which documented ten indicators that civic health in the United States is declining. Two of these ten indicators included that the US ranked 139 in voter participation, out of 172 world democracies in 2007, and that only 10\% of US citizens contacted a public official in 2009-2010 [19].

Within the academy, civic engagement is often used as an umbrella term that includes pedagogical tools such as service-learning, community-based research, episodic service, and service immersion. Ehrlich, et al. [20] (p. iv), defines civic engagement as:

Working to make a difference in the civic life of our communities and developing the combination of knowledge, skills, values, and motivations to make that difference. It means promoting the quality of life in a community, through political and non-political processes.

It is civic engagement's foundation in experiential, place-based learning that is designed to support local and regional communities that connects it to sustainability literacy [18]. Like Ehrlich [20], Cortese believed that "Higher education institutions bear a profound, moral responsibility to increase the awareness, knowledge, skills, and values needed to create a just and sustainable future" [18] (p. 17). Through a shared belief in positive sustainable change and the idea that "designing a sustainable 
human future requires a paradigm shift towards a systemic perspective emphasizing collaboration and cooperation" [18] (p. 16), CofC's Center for Civic Engagement and the SLI saw an opportunity to collaborate and use a service immersion program, alternative breaks, to build students' civic and sustainability related competencies. This partnership was further solidified through CS 3.3.2, which led to alternative breaks being written into the QEP as a program that could be used to measure learning goals and SLOs related to sustainability literacy. Additionally, CofC's alternative break program served as an important structure that tied the QEP to CofC's co-curricular initiatives, assuring that the QEP had a broad-based involvement.

\section{Alternative Break}

In what follows, we give an overview contextualizing the Center for Civic Engagement (CCE) and alternative breaks at CofC to clarify the intricacies of the program and how they fit into partnership with the SLI. Housed in the Division of Student Affairs at CofC, the mission of the CCE is to contribute to the holistic development of College of Charleston students and to cultivate in them a passion for positive social change through the use of education, service, and critical reflection. Through co-curricular community engagement initiatives, the CofC's Center for Civic Engagement lives out its mission.

One of the CCE's more popular programs is alternative break, a service-immersion experience where students spend their academic breaks traveling to different parts of the country to address and learn about sustainable/unsustainable practices through community service work. CofC's alternative break program is a member of Break Away, a national organization that supports colleges and universities across the country to implement quality alternative breaks. As such, CofC's alternative break program is designed to move students from members of their communities, individuals who are not concerned about community issues, to active citizens, individuals who place community as a priority in their values and life choices [21].

Alternative break programs are common at institutions of higher education across the country. According to Break Away's [22] National Alternative Break Survey, there are approximately 195 alternative break programs in the United States. Unlike other forms of service immersion, including mission trips and service-learning trips, alternative breaks differ in that they are guided by eight components: (1) strong direct service; (2) alcohol and drug free; (3) diversity and social justice; (4) orientation; (5) education; (6) training; (7) reflection; and (8) reorientation [21]. The CofC's alternative break program addresses each of Break Away's eight components; however, their program includes a ninth component, "community impact," as the program believes in the importance of understanding the type of impact they have on the communities they work with each year. CofC's alternative break program strives to maintain sustainable partnerships through working with the same organizations in the same communities over time. Through assessment and evaluations, the CofC alternative break program hopes to limit some of the pitfalls that are common in university-community partnerships, like wasting resources and poor communication [23-25].

Each year, the CofC alternative break program organizes four to five trips over spring break. A full trip includes nine student participants, two student site leaders, and one faculty/staff advisor. In the months leading up to the trip, each group meets regularly to build a positive group dynamic, learn about the social, economic, environmental, and historical context of the communities they will be working with, and to build the soft skills (e.g., language) and hard skills (e.g., construction) that they may need during their alternative break experience. While on the trips, each group meets regularly to reflect on their service and how it relates to the education, orientation, and training that they received before they left. Reflections are a key component of alternative breaks and any other form of experiential learning [21,26-28]. Reflections are designed to encourage students to reflect on their own personal and collective behaviors to understand how they have personally and collectively contributed to the unsustainable and oppressive systems they are addressing during their alternative break experience. Further, once the group returns, they meet again to discuss how they can take what 
they learned during their experience and apply it to their home communities and day to day lives, including on campus.

While there is an abundance of literature [29-34] that focuses on the benefits of service-learning and episodic community service on students, there is limited literature in comparison on how alternative breaks specifically impact students (Beatty et al.) [35]. More importantly, there is little to no literature on how alternative breaks build sustainability literacy. While this is not an extensive literature review on alternative breaks, it does highlight some of the work done on alternative breaks and their impact on students. According to Niehaus [36], alternative breaks link two high-impact practices, community-based learning and diversity/global learning. As mentioned previously, high-impact practices are directly correlated to retention and student success [16]. Beatty et al. [35] found that students that participate in co-curricular alternative breaks self-report positive attitudes towards community service, a significant amount of personal growth, a desire to help others following their experience, and an increased awareness of issues impacting society. Jones et al. [37], also found that students that participate in alternative breaks report that they have a better understanding of social issues because of their involvement in alternative breaks. In addition, Bowen [38], found similar results to Beatty et al. [35], indicating that students that participated in alternative breaks expressed a commitment to community service and involvement. Niehaus [36] found that through successful reorientation and reflection on their engagement with others during their alternative beak, students reported positive changes in their understanding of social justice. Further, students that participate in alternative breaks report that their experience had an impact on their career goals and aspirations [39]. Since sustainability education and civic engagement both foster the competencies necessary to build and advocate for sustainable communities, the SLI and CCE believed that alternative breaks could build students' sustainability literacy. With this context for alternative break in place, we now give an overview of how the SLI assessed the alternative break program and what we learned from the process.

\section{Assessment Process}

Due to the nature of alternative breaks as an experiential learning program that allows students to work within and learn about social, environmental, and economic systems, it made strategic and institutional sense to assess CofC's alternative break program by student learning outcomes associated with sustainability literacy. In particular, CofC's QEP goals related to integrating and synthesizing knowledge, building skills and competencies, and becoming change agents for resiliency were measured through the assessment process.

Reflection is often credited for where learning actually happens in service-learning and alternative breaks [21-24]. In addition to nightly group reflections, students complete a reflection journal while on their trips. The journals include several questions that guide students' reflection process and encourages them to think critically about their service experience.

Prior to the CCE's partnership with the SLI, alternative break reflection journals were assessed using a revised Association of American Colleges and Universities (AAC\&U) Civic Engagement VALUE Rubric [40] (See Appendix for Table A1). When the QEP started in 2016, the SLI saw an opportunity to leverage the value already generated in the alternative break program to further inculcate students with sustainability literacy skills. In response, the CCE revised their reflection journal to include three QEP specific questions/prompt: (1) How has this alternative break experience exposed you to sustainable or unsustainable policies and practices?; (2) Talk about how alternative break influenced what you think about yourself, the issue, and/or the social, economic, and environmental systems which you are a part of.; (3) How can you advocate for a more sustainable solution to the issue(s) addressed through your alternative break? The following QEP student learning outcomes were then measured through the evaluation and scoring of the journals:

(1) SLO3: Students will identify policies and practices that have led to unsustainability.

(2) SLO5: Students will demonstrate the impact of production/consumption practices on social, economic, and/or ecological systems. 
(3) SLO7: Students are advocates for resiliency at the individual, institutional, community, national, or international level.

These outcomes were directly measured using an internally-developed four-point scale sustainability literacy rubric (See Appendix for Table A2) that was created by faculty and staff associated with the QEP. Before the qualitative assessment, campus reviewers went through a rubric and scoring training provided by the associate director of the CCE, who was also a member of the QEP Assessment Team and also the QEP's Curricular and Co-curricular subcommittee. This training provided a full explanation of the alternative break program and the sustainability literacy rubric to maximize inter-rater reliability. Next, teams of three rated each reflection journal and then convened to discuss discrepancies in scoring that had a difference of more than one rating level.

\section{Assessment Results}

In the 2016-2017 academic year, students in the alternative break program had not yet been introduced to sustainability education and training in their pre-trip meetings. The QEP Assessment Team capitalized on this opportunity and assessed 52 reflection journals to determine a baseline for SLO 3, SLO 5, and SLO 7.

As illustrated in Figure 1, the Assessment Team found that the mean score for SLO 3, identify policies and practices that have led to unsustainability, was 1.6331, below the average score of 2.0 as defined by the sustainability literacy rubric, and as such it fell in the below-average range. Student work did not identify unsustainable policies/practices. For SLO 5, demonstrates the impact of production-consumption practices on social, economic, and/or environmental systems, the mean score was 1.3981 (below average), student work did not indicate at least one production-consumption practice, or did not address the impact of social, economic, and/or environmental systems. Further, the Assessment Team found that the mean score for SLO 7, advocate for resiliency at various levels, was 1.6669 (below average), student work did not advocate for resiliency or only advocated at the individual level. Given these year 0 findings, the baseline of student's sustainability literacy within an alternative break context was set at below average for all three SLOs.

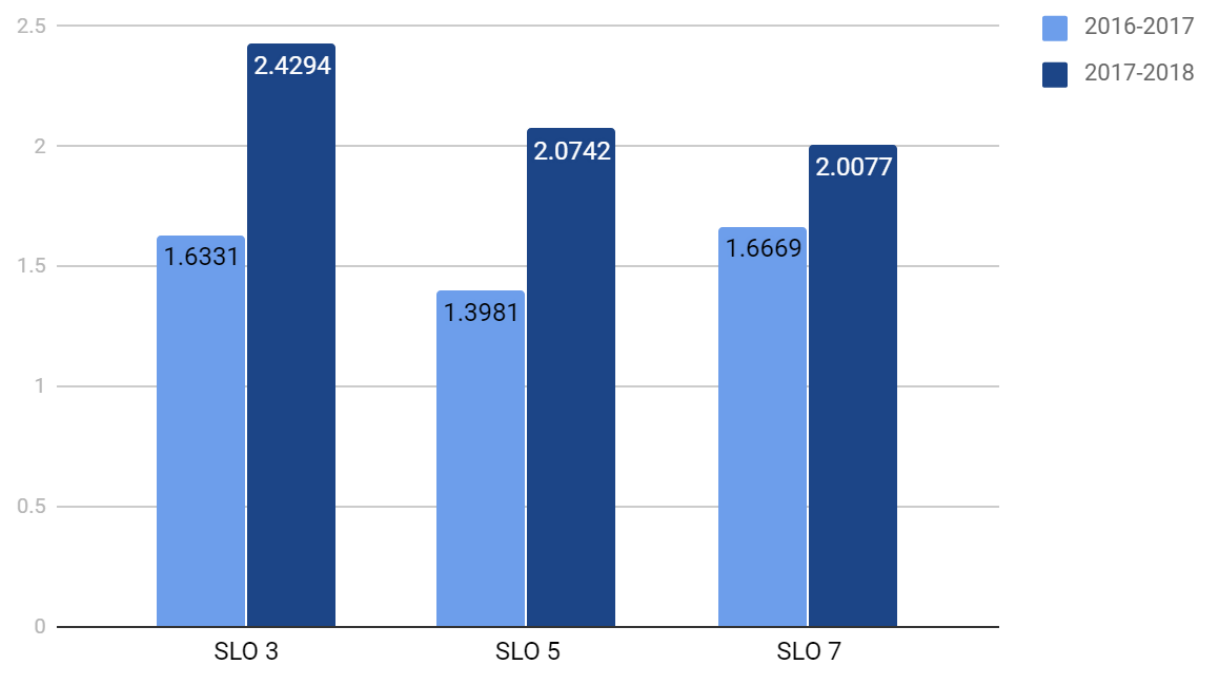

Figure 1. Alternative break sustainability literacy assessment results 2016-2017 and 2017-2018.

During the 2017-2018 academic year, 48 refection journals were assessed. This cohort of alternative breakers were exposed to sustainability education in their pre-trip meetings. In addition, their student site leaders were trained on how to facilitate discussions on sustainability. As shown in Figure 1, the Assessment Team found that the mean score for SLO 3, identify policies and practices that have led to unsustainability, was 2.429 , an average score according to the sustainability literacy rubric. Student 
work identified at least one unsustainable policy/practice. The mean score for SLO 5, demonstrate the impact of production-consumption practices on social, economic, and/or ecological systems was 2.1650, an average score that indicated the reflection journals illustrated that students indicated at least one sustainable/unsustainable practice and provided some explanation of its impact on systems. In addition, the mean score for SLO 7, advocate for resiliency at various levels, was 2.0077, a score of average, indicating that student work demonstrated some understanding of triple bottom line problems and resiliency, and advocated for resiliency beyond the individual level.

Mann-Whitney U tests were run to determine if there were differences in students' sustainability literacy scores between the (2016-2017 group) and the (2017-2018 group). For the SLO 3 outcome measure, the median literacy score was statistically significantly higher for the 2017-2018 group (2.33) compared to the 2016-2017 group (1.67), $U=498, z=-5.24, p \leq 0.001$. For the SLO 5 outcome measure, the median literacy score was statistically significantly higher for the 2017-2018 group (2.17) compared to the 2016-2017 group (1.17), $U=567, z=-4.81, p \leq 0.001$. Further, for the SLO 7 outcome measure, the median literacy score was statistically significantly higher for the 2017-2018 group (2.00) compared to the2016-2017 group (1.33), $U=780, z=-3.30, p=0.001$.

\section{Discussion and Recommendations}

The Assessment Team found that students' sustainability literacy scores increased after being exposed to sustainability-focused education in their pre-trip meetings and site leader training. This means that sustainability literacy was successfully implemented into the CofC's alternative break program. Through participating in sustainability-themed alternative breaks, students were able to identify unsustainable policies and practices and provide some explanation of their impact on social, environmental, and economic systems. Additionally, students that participated in sustainability-themed alternative breaks were able to understand the triple bottom line and illustrate how they could advocate for resiliency beyond just the individual level.

While the students' sustainability literacy scores were statistically significantly higher for the 2017-2018 group for SLO 3, SLO 5, and SLO 7, these increases were not as high as the QEP Assessment Team hoped. The QEP Assessment Team hypothesizes that this may have to do with some of the pedagogical limitations of the alternative break program. The above learning and assessment of socio-economic focused civic engagement and student-partnership-centered learning points to certain structural and pedagogical limitations. The College is using the assessment process to reflect on strategies to address these limits as much as possible. Additionally, the authors acknowledge that assessment bias was a limitation to this study. The authors' positionality and proximity to the QEP informed how they viewed the assessment results.

Gaps in programming and needs of student learning as articulated by the QEP, have emerged in the two years of this partnership. These gaps result from the structural deficiencies such as the time-deficit nature of current student commitments. As the alternative break partnerships exist off campus and out of state, it is impossible to thoroughly prepare students to understand the socio-ecologic context of the site and the work being done by the host partner. The advocacy work being done by partners is nuanced, complex, multi-sector, and longitudinal. It can be challenging to grasp this complexity, or the various structural impediments that exist in mainstream society that impact the success rate of partner hosts and their advocacy work. However, many students catch a glimpse of these various challenges the host partners face, and this is a key learning outcome of the alternative break partnerships. Redesigning a sustainable future is not easy, and these alternative break experiences help students see this.

Another structural impediment is the busy schedule of students at the College. Alternative break occurs over spring break but requires weekly meetings over six months as a lead up to the actual trip. These meetings are overseen by the student site leaders and since alternative break is not credit bearing, there are minimal leverage points to demand students undertake a lot of preparatory readings or engage in in-depth workshops and training. This time deficit means there is less opportunity to prepare students to fully understand the goals of sustainability literacy and civic engagement. 
This is compounded by a return to campus where there are not continued post-trip meetings past the reorientation meeting to further help students decompress and strategize ways they can take the knowledge gained on their alternative break and apply it to CofC's campus or the larger Charleston community. Mentoring alternative break participants in a post-trip context so that they can engage in socio-ecological civic work in the Charleston area (including on campus) is a future strategy, although dealing with post-trip fatigue may prove to be an impediment to this. It may even be strategic to require SLI student ambassadors to serve as student site leaders. SLI student ambassadors work directly with the SLI and therefore are more familiar with sustainability education than traditional alternative break student site leaders. These students can then mentor alternative break participants post-trip and encourage their peers to remain engaged in sustainability efforts on campus or in the Charleston region.

In addition, the alternative break program should investigate offering a credit-bearing alternative break experience tied to an academic credit-bearing course in sustainability. According to Vogelgesang and Astin [41], student learning significantly increases when community service is tied to academic credit compared to only a co-curricular community service experience. Utilization of the SLI Fellows to teach a credit-bearing alternative break experience could lead to higher student sustainability literacy scores.

Alternative breaks are also not financially accessible to all students. Designing alternative breaks to be more affordable can lead to an increase in student participation, thus allowing the institution to reach a larger number of students. Assessment can service an important role in securing additional financial resources from an institution. Illustrating that students are indeed learning from alternative break experiences can incentivize admiration to put more financial resources behind the program.

Further, it is important to take a critical look at alternative break programs as a practice that perpetuates unsustainable systems. If educators are to continue to use alternative breaks as a pedagogical tool to foster active citizenship and sustainability literacy, they must look into how they can design an alternative break that fits into what Stewart and Nicolazzo [42] call "trickle-up high impact practices" (TUHIPs). For example, as Stewart and Nicolazzo [42] point out, HIPs are grounded in whiteness and often omit and/or endanger students who are at the most marginalized axis of oppression (i.e., trans* disabled women of color). (The asterisk in the word trans* is used to symbolize the multiplicity of identities within the gender identity spectrum that do not include a cisgender man or woman $[42,43]$.) These TUHIPs should also be integrated into the entire reaccreditation process and QEP.

Lastly, we point to the internal inconsistency and hypocrisy that attends to fossil-fuel-based travel on a planet undergoing rapid anthropogenic climate change. In short, how can the College (and this applies to all institutes of higher education who utilize fossil fuels to transport students to games, study away trips, conferences, and other learning opportunities) justify flying students to host communities when this carries with it a carbon footprint? This is an unresolved tension, a possible solution to which is only to partner with groups within a five-hour driving radius.

\section{Conclusions}

This paper has shared CofC's reaccreditation efforts where the institute has pledged support to embedding sustainability literacy across curricular and co-curricular settings. One area of innovation within this project has been to explore social, environmental, and economic "wicked problems" within the context of alternative break civic engagement. The preliminary findings of these efforts, based on two years of journal evaluations and feedback from on-site student leaders, is that community-and-project-based learning, broadly, but also within the context of sustainability in higher education, needs increased collaboration and partnership building. This needs to occur both on campus, and between a campus and its community partners. 
Capturing the nuanced goals of sustainability literacy as defined in CofC's QEP requires year-long learning groups that are embedded with local civic engagement groups. This type of partnership is easy to assess; can lead to larger longitudinal gains; allows for more tie-in to current classes that students are taking; helps to bolster Carnegie Classification for Community Engagement and the Association of the Advancement of Sustainability in Higher Education's Sustainability Tracking, Assessment and Rating System (STARS), both; and key for this article, creates a context that carries with it more potential for social change than does a week-long site visit in a receiving community hundreds of miles away.

In this era of a "viability of democracy" [44] (p. 54), where students need to receive sustainability competencies within a larger institutional context where sustainability is taken seriously, service-immersed civic engagement is a powerful vehicle. Utilizing campus-wide reaccreditation processes to help build cross-campus sustainability literacy partnerships, as undertaken by the College, can help institutes of higher education quickly and strategically embed sustainability competencies throughout campus curricular and co-curricular offerings. Taken together these reaccreditation-based partnerships can help deliver the tools necessary to construct a more socially-just and environmentally-healthy future, while giving students the authority to understand and change this century's wicked problems [45].

Author Contributions: Co-author T.L. wrote the introduction and sections on the QEP and SLI. Co-author C.C. wrote the sections on alternative breaks and the assessment of the alternative break journals. Both authors co-wrote the conclusion. The authors would also like to thank Travis Riffle for their help with the formal analysis of the reflection journals.

Funding: This research received no external funding.

Acknowledgments: The authors wish to thank the Sustainability Literacy Institute, Office of Sustainability, and the Center for Civic Engagement at the College of Charleston, SC.

Conflicts of Interest: The authors declare no conflicts of interest. 


\section{Appendix A}

Table A1. Center for Civic Engagement to assess student learning. This rubric is adapted from the Civic Engagement Value Rubric developed by the Association of American Colleges \& Universities.

\begin{tabular}{|c|c|c|c|c|}
\hline & Capstone & Miles & ones & Benchmark \\
\hline $\begin{array}{l}\text { Diversity of Communities } \\
\text { and Cultures } \\
\text { (Civic Knowledge) }\end{array}$ & $\begin{array}{l}\text { Demonstrates evidence of adjustment in } \\
\text { own attitudes and beliefs because of } \\
\text { working within and learning from diversity } \\
\text { of communities and cultures. Promotes } \\
\text { others' engagement with diversity. }\end{array}$ & $\begin{array}{l}\text { Reflects on how own attitudes and } \\
\text { beliefs are different from those of other } \\
\text { cultures and communities. Exhibits } \\
\text { curiosity about what can be learned } \\
\text { from diversity of communities } \\
\text { and cultures. }\end{array}$ & $\begin{array}{l}\text { Has awareness that own attitudes and } \\
\text { beliefs are different from those of } \\
\text { other cultures and communities. } \\
\text { Exhibits little curiosity about what can } \\
\text { be learned from diversity of } \\
\text { communities and cultures. }\end{array}$ & $\begin{array}{l}\text { Expresses attitudes and beliefs as an } \\
\text { individual, from a one-sided view. } \\
\text { Is indifferent or resistant to what } \\
\text { can be learned from diversity of } \\
\text { communities and cultures. }\end{array}$ \\
\hline $\begin{array}{l}\text { Analysis of Knowledge } \\
\text { (Civic Knowledge) }\end{array}$ & $\begin{array}{l}\text { Connects and extends knowledge (facts, } \\
\text { theories, etc.) from one's own academic } \\
\text { study/ field/discipline to alternative break } \\
\text { and to one's own participation in civic life, } \\
\text { politics, and government. }\end{array}$ & $\begin{array}{l}\text { Analyzes knowledge (facts, theories, } \\
\text { etc.) from one's own academic } \\
\text { study/field/discipline making relevant } \\
\text { connections to alternative break and to } \\
\text { one's own participation in civic life, } \\
\text { politics, and government. }\end{array}$ & $\begin{array}{l}\text { Begins to connect knowledge (facts, } \\
\text { theories, etc.) from one's own } \\
\text { academic study/field/discipline to } \\
\text { civic engagement and to one's own } \\
\text { participation in civic life, politics, } \\
\text { and government. }\end{array}$ & $\begin{array}{l}\text { Begins to identify knowledge (facts, } \\
\text { theories, etc.) from one's own } \\
\text { academic study/field/discipline that } \\
\text { is relevant to alternative break and } \\
\text { to one's own participation in civic } \\
\text { life, politics, and government. }\end{array}$ \\
\hline $\begin{array}{l}\text { Civic Identity and } \\
\text { Commitment } \\
\text { (Civic Values) }\end{array}$ & $\begin{array}{l}\text { Provides evidence of experience in } \\
\text { alternative break activities and describes } \\
\text { what they learned about themselves as it } \\
\text { relates to a reinforced and clarified sense of } \\
\text { civic identity and continued commitment to } \\
\text { active citizenship. }\end{array}$ & $\begin{array}{l}\text { Provides evidence of experience in } \\
\text { alternative break activities and describes } \\
\text { what they learned about themselves as it } \\
\text { relates to a growing sense of } \\
\text { civic-identity and commitment. }\end{array}$ & $\begin{array}{l}\text { Evidence suggests involvement in } \\
\text { alternative break is generated from } \\
\text { expectations or requirement rather } \\
\text { than from a sense of civic-identity. }\end{array}$ & $\begin{array}{l}\text { Provides little evidence of their } \\
\text { 1alternative break experience and } \\
\text { does not connect experiences to } \\
\text { civic-identity. }\end{array}$ \\
\hline $\begin{array}{l}\text { Civic Contexts/Structures } \\
\text { (Civic Values) }\end{array}$ & $\begin{array}{l}\text { Demonstrates ability and commitment to } \\
\text { collaboratively work across and within } \\
\text { community contexts and structures to } \\
\text { achieve a civic aim. Community has become } \\
\text { a priority in their values and life choices. }\end{array}$ & $\begin{array}{l}\text { Demonstrates ability and commitment } \\
\text { to work actively within community } \\
\text { contexts and structures to achieve a civic } \\
\text { aim. This person also demonstrates that } \\
\text { they are concerned about root causes. }\end{array}$ & $\begin{array}{l}\text { Demonstrates experience identifying } \\
\text { intentional ways to participate in civic } \\
\text { contexts and structures; they are } \\
\text { well-intentioned but not well } \\
\text { educated about social issues. }\end{array}$ & $\begin{array}{l}\text { Experiments with civic contexts and } \\
\text { structures,but is not concerned with } \\
\text { their role in social problems. }\end{array}$ \\
\hline $\begin{array}{l}\text { Civic Communication } \\
\text { (Civic Skills) }\end{array}$ & $\begin{array}{l}\text { Tailors communication strategies to } \\
\text { effectively express, listen, and adapt to } \\
\text { others to establish relationships to further } \\
\text { civic action. }\end{array}$ & $\begin{array}{l}\text { Effectively communicates in civic } \\
\text { context, showing ability to do all of the } \\
\text { following: express, listen and adapt } \\
\text { ideas and messages based on } \\
\text { others' perspectives. }\end{array}$ & $\begin{array}{l}\text { Communicates in civic context, } \\
\text { showing ability to do more than one } \\
\text { of the following: express, listen and } \\
\text { adapt ideas and messages based on } \\
\text { others' perspectives. }\end{array}$ & $\begin{array}{l}\text { Communicates in civic context, } \\
\text { showing ability to do one of the } \\
\text { following: express, listen and adapt } \\
\text { ideas and messages based on others' } \\
\text { perspectives. }\end{array}$ \\
\hline $\begin{array}{l}\text { Civic Action and Reflection } \\
\text { (Civic Skills) }\end{array}$ & $\begin{array}{l}\text { Demonstrates independent experience and } \\
\text { shows initiative in leadership of complex or } \\
\text { multiple civic engagement 0activities, } \\
\text { accompanied by reflective insights or } \\
\text { analysis about the aims and } \\
\text { accomplishments of one's actions. }\end{array}$ & $\begin{array}{l}\text { Demonstrates independent experience } \\
\text { and reflects on their own actions and } \\
\text { how their actions affect others. }\end{array}$ & $\begin{array}{l}\text { Has clearly participated in } \\
\text { civically-focused actions and begins to } \\
\text { reflect or describe how these actions } \\
\text { may benefit individual(s) } \\
\text { or communities. }\end{array}$ & $\begin{array}{l}\text { Participated in alternative break but } \\
\text { shows little internalized } \\
\text { understanding of its aims or effects } \\
\text { and little commitment to } \\
\text { future action. }\end{array}$ \\
\hline
\end{tabular}


Table A2. Sustainability literacy rubric used to assess alternative break journals.

\begin{tabular}{|c|c|c|c|c|}
\hline Outcome & Below Average (1) & Average (2) & Above Average (3) & Exceptional (4) \\
\hline $\begin{array}{l}\text { Identify various elements of } \\
\text { sustainability and } \\
\text { relationships between them } \\
\text { (SLO 1) }\end{array}$ & Student work identifies 0 or 1 elements. & $\begin{array}{l}\text { Student work identifies at least } 2 \\
\text { elements, but does not describe the } \\
\text { relationship between them. }\end{array}$ & $\begin{array}{l}\text { Student work identifies } 2 \text { or more } \\
\text { elements and provides some } \\
\text { description of the relationships } \\
\text { between them. }\end{array}$ & $\begin{array}{l}\text { Student work identifies all } \\
3 \text { elements and provides a } \\
\text { comprehensive description of the } \\
\text { relationships between them. }\end{array}$ \\
\hline $\begin{array}{l}\text { Identify key ways to be more } \\
\text { sustainable in personal life } \\
\text { and on-campus } \\
\text { (SLO 2) }\end{array}$ & $\begin{array}{l}\text { Student work does not identify ways to be } \\
\text { more sustainable. }\end{array}$ & $\begin{array}{l}\text { Student work identifies at least } 1 \\
\text { way to be more sustainable. }\end{array}$ & $\begin{array}{l}\text { Student work identifies } 2 \text { or more } \\
\text { ways and provides some } \\
\text { description of their relationships } \\
\text { with sustainability. }\end{array}$ & $\begin{array}{l}\text { Student work identifies } 2 \text { or more } \\
\text { ways, provides a comprehensive } \\
\text { description of their relationships } \\
\text { with sustainability, and connects } \\
\text { them to course content. }\end{array}$ \\
\hline $\begin{array}{l}\text { Identify policies and practices } \\
\text { that have led to } \\
\text { unsustainability. } \\
\text { (SLO 3) }\end{array}$ & $\begin{array}{l}\text { Student work does not identify } \\
\text { unsustainable policies/practices. }\end{array}$ & $\begin{array}{l}\text { Student work identifies at least } 1 \\
\text { unsustainable policy/practice. }\end{array}$ & $\begin{array}{l}\text { Student work identifies and } \\
\text { provides some description of } 2 \text { or } \\
\text { more unsustainable } \\
\text { policies/practices. }\end{array}$ & $\begin{array}{l}\text { Student work identifies and } \\
\text { provides a comprehensive } \\
\text { description of } 2 \text { or more major } \\
\text { unsustainable policies/practices, } \\
\text { and connects them to other } \\
\text { course content. }\end{array}$ \\
\hline $\begin{array}{l}\text { Synthesize knowledge from } \\
\text { two or more systems to } \\
\text { address a sustainability } \\
\text { problem. } \\
\text { (SLO 4) }\end{array}$ & $\begin{array}{l}\text { Student work does not incorporate } \\
\text { knowledge from } 2 \text { or more systems. }\end{array}$ & $\begin{array}{l}\text { Student work incorporates, but does } \\
\text { not synthesize, knowledge from } 2 \text { or } \\
\text { more systems. }\end{array}$ & $\begin{array}{l}\text { Student work incorporates and } \\
\text { synthesizes knowledge from } 2 \text { or } \\
\text { more systems. }\end{array}$ & $\begin{array}{l}\text { Student work incorporates and } \\
\text { synthesizes knowledge from all } \\
3 \text { systems, and connects them to } \\
\text { other course content. }\end{array}$ \\
\hline $\begin{array}{l}\text { Demonstrate the impact of } \\
\text { production - consumption } \\
\text { practices on social, economic, } \\
\text { and/or ecological systems. } \\
\text { (SLO 5) }\end{array}$ & $\begin{array}{l}\text { Student work does not indicate at least } \\
1 \text { practice, or does not to address impact } \\
\text { of systems. }\end{array}$ & $\begin{array}{l}\text { Student work indicates at least } 1 \\
\text { practice and provides some } \\
\text { explanation of its impact } \\
\text { on systems. }\end{array}$ & $\begin{array}{l}\text { Student work indicates } 2 \text { or more } \\
\text { practices and provides some } \\
\text { explanation of their impact } \\
\text { on systems. }\end{array}$ & $\begin{array}{l}\text { Student work indicates } 2 \text { or more } \\
\text { major practices, and provides a } \\
\text { comprehensive explanation of their } \\
\text { impact on systems. }\end{array}$ \\
\hline $\begin{array}{l}\text { Design a solution to a given } \\
\text { sustainability problem. } \\
\text { (SLO 6) }\end{array}$ & $\begin{array}{l}\text { Student work provides no outline of an } \\
\text { effective solution. }\end{array}$ & $\begin{array}{l}\text { Student work provides some outline } \\
\text { of an effective solution. }\end{array}$ & $\begin{array}{l}\text { Student work provides an effective } \\
\text { solution and some strategies for } \\
\text { implementing the solution. }\end{array}$ & $\begin{array}{l}\text { Student work provides an effective } \\
\text { solution and strategies for } \\
\text { implementing the solution, which } \\
\text { address multiple stakeholders } \\
\text { and systems. }\end{array}$ \\
\hline
\end{tabular}


Table A2. Cont.

\begin{tabular}{|c|c|c|c|c|}
\hline Outcome & Below Average (1) & Average (2) & Above Average (3) & Exceptional (4) \\
\hline $\begin{array}{l}\text { Advocate for resiliency at } \\
\text { various levels. } \\
\text { (SLO 7) }\end{array}$ & $\begin{array}{l}\text { Student work does not advocate for } \\
\text { resiliency or only advocates at the } \\
\text { individual level. }\end{array}$ & $\begin{array}{l}\text { Student work demonstrates some } \\
\text { understanding of TBL problems and } \\
\text { resiliency, and advocates for } \\
\text { resiliency beyond the individual } \\
\text { level (campus, community, } \\
\text { national, international). }\end{array}$ & $\begin{array}{l}\text { Student work demonstrates a } \\
\text { comprehensive understanding of } \\
\text { TBL problems and resiliency, and } \\
\text { advocates for resiliency with } \\
\text { multiple stakeholders beyond the } \\
\text { individual level (campus, } \\
\text { community, national, international). }\end{array}$ & $\begin{array}{l}\text { Student work demonstrates a } \\
\text { comprehensive understanding of } \\
\text { TBL problems and resiliency, and } \\
\text { advocates for resiliency with } \\
\text { multiple stakeholders beyond the } \\
\text { campus level (community, } \\
\text { national, international). }\end{array}$ \\
\hline $\begin{array}{l}\text { Communicate effectively } \\
\text { following the conventions of } \\
\text { the course discipline(s). }\end{array}$ & $\begin{array}{l}\text { Student work is impeded by many } \\
\text { grammatical or mechanical errors, and/or } \\
\text { does not appropriately rely on the } \\
\text { communication conventions of the discipline } \\
\text { (integrating and citing sources. etc.) }\end{array}$ & $\begin{array}{l}\text { Student work has some } \\
\text { grammar/mechanic errors, or minor } \\
\text { difficulties with the communication } \\
\text { conventions of the discipline. }\end{array}$ & $\begin{array}{l}\text { Student work is free of serious } \\
\text { grammar and/or mechanical errors } \\
\text { and follows appropriate } \\
\text { disciplinary conventions. }\end{array}$ & $\begin{array}{l}\text { Student work employs clear, } \\
\text { stylistically mature language } \\
\text { appropriate to the discipline and is } \\
\text { free of serious grammatical, } \\
\text { mechanical, and citation errors. }\end{array}$ \\
\hline
\end{tabular}




\section{References and Notes}

1. College of Charleston. Available online: http://cofc.edu/ (accessed on 14 December 2018).

2. Gaston, P. Higher Education Accreditation: How It's Changing, Why It Must; Stylus Publishing: Sterling, VA, USA, 2014.

3. Stough, T.; Ceulemans, K.; Lambrechts, W.; Cappuyns, V. Assessing sustainability in higher education curricula: A critical reflection on validity issues. J. Clean. Prod. 2017, 172, 4456-4466. [CrossRef]

4. Chronicle of Higher Education. Available online: https://www.chronicle.com/article/Accreditation-in-Action/145883 (accessed on 5 December 2018).

5. Southern Association of Colleges and Schools Commission on Colleges. Available online: http://www. sacscoc.org/pdf/webmemlist.pdf (accessed on 10 May 2019).

6. Southern Association of Colleges and Schools Commission on Colleges. Available online: http://www. sacscoc.org/pdf/Quality\%20Enhancement\%20Plan\%20Guidelines.pdf (accessed on 5 December 2018). It is noted that these standards have since been changed by SACSCOC but for this article we reference the old standards that guide CofC's QEP on sustainability literacy.

7. College of Charleston. Available online: http://www.cofc.edu/about/missionvisionvalues/index.php (accessed on 10 May 2019).

8. College of Charleston. Available online: http://www.cofc.edu/strategicplan/documents/strategic-plan.pdf (accessed on 5 December 2018).

9. Disterheft, A.; Caeiro, S.; Azeiteiro, U.M.; Leal Filho, W. Sustainable universities-a study of critical success factors for participatory approaches. J. Clean. Prod. 2015, 106, 11-21. [CrossRef]

10. The College also has an Office of Sustainability (OOS) which is in-part focused on applied internships and operational management around sustainability; and a Center for Sustainability, within which the SLI and OOS reside and that focuses on research and knowledge advancement around sustainability. Available online: http://sustainability.cofc.edu/ (accessed on 13 September 2019).

11. College of Charleston Quality Enhancement Plan. Available online: http://oiep.cofc.edu/documents/qep/subcommittees/QEP\%20Booklet\%202.14.17.pdf (accessed on 5 December 2018).

12. Fisher, B.; McAdams, E. Gaps in sustainability education: The impact of higher education coursework on perceptions of sustainability. Int. J. Sustain. High. Educ. 2015, 16, 407-423. [CrossRef]

13. Gosselin, D.; Parnell, R.; Smith-Sebasto, N.J.; Vincent, S. Integration of sustainability in higher education: Three case studies of curricular implementation. J. Environ. Stud. Sci. 2013, 3, 316-330. [CrossRef]

14. Ávila, L.V.; Leal Filho, W.; Brandli, L.; Macgregor, C.J.; Molthan-Hill, P.; Özuyar, P.G.; Moreira, R.M. Barriers to innovation and sustainability at universities around the world. J. Clean. Prod. 2017, 164, 1268-1278. [CrossRef]

15. Thomashow, M. The Nine Elements of a Sustainable Campus; The MIT Press: Cambridge, MA, USA, 2014.

16. Kuh, G.D.; Kinzie, J.; Schuh, J.H.; Whitt, E.J. Student Success in College: Creating Conditions that Matter; John Wiley \& Sons: Washington, DC, USA, 2005.

17. Boyer, E.L. Scholarship Reconsidered: Priorities of the Professoriate; Carnegie Foundation for the Advancement of Teaching: San Francisco, CA, USA, 1990.

18. Cortese, A.D. The critical role of higher education in creating a sustainable future. Plan. High. Educ. 2003, 31, 15-22.

19. The National Task Force on Civic Learning and Democratic Engagement. A Crucible Moment: College Learning and Democracy's Future; Association of American Colleges and Universities: Washington, DC, USA, 2012.

20. Ehrlich, T. Civic Responsibility and Higher Education; Rowman \& Littlefield: New York, NY, USA, 2000.

21. Sumka, S.; Porter, M.C.; Piacitelli, J. Working Side by Side: Creating Alternative Breaks as a Catalyst for Global Learning, Student Leadership, and Social Change; Stylus Publishing, LLC: Sterling, VA, USA, 2015.

22. Break Away National Alternative Break Survey 2017-2018. Available online: http://alternativebreaks.org/ wp-content/uploads/2018/09/2018-National-Alternative-Break-Survey.pdf (accessed on 30 May 2019).

23. Blouin, D.D.; Perry, E.M. Whom does service learning really serve? Community based organization perspectives on service learning. Teach. Sociol. 2009, 37, 120-135. [CrossRef]

24. Sandy, M.; Holland, B.A. Different worlds and common ground: Community partner perspectives on campus-community partnerships. Mich. J. Community Serv. Learn. 2006, 13, 30-43. 
25. Tryon, E.; Stoecker, R.; Martin, A.; Seblonka, K.; Hilgendorf, A.; Nellis, M. The challenge of short-term service-learning. Mich. J. Community Serv. Learn. 2008, 14, 16-26.

26. Hatcher, J.A.; Bringle, R.G. Reflection: Bridging the gap between service and learning. Coll. Teach. 1997, 45, 153-158. [CrossRef]

27. Jacoby, B. Service-Learning in Higher Education: Concepts and Practices. The Jossey-Bass Higher and Adult Education Series; Jossey-Bass Publishers: San Francisco, CA, USA, 1996.

28. Piacitelli, J.; Barwick, M.; Doerr, E.; Porter, M.; Sumka, S. Alternative break programs: From isolated enthusiasm to best practices: The Haiti compact. J. High. Educ. Outreach Engagem. 2013, 17, 87-110.

29. Astin, A.W.; Sax, L.J. How undergraduates are affected by service participation. J. Coll. Stud. Dev. 1998, 39, 251-263.

30. Astin, A.W.; Vogelgesang, L.J.; Ikeda, E.K.; Yee, J.A. How service learning affects students. Available online: https://digitalcommons.unomaha.edu/cgi/viewcontent.cgi?article=1145\&context=slcehighered (accessed on 26 August 2019).

31. Avalos, J.; Sax, L.J.; Astin, A.W. The long-term effects of volunteerism during the undergraduate years. Rev. High. Educ. 1999, 22, 187-202.

32. Eyler, J.; Giles, D.E., Jr. Where's the Learning in Service-Learning? Jossey-Bass Higher and Adult Education Series; Jossey-Bass, Inc.: San Francisco, CA, USA, 1999.

33. Simons, L.; Cleary, B. The influence of service learning on students' personal and social development. Coll. Teach. 2006, 54, 307-319. [CrossRef]

34. Warren, J.L. Does service-learning increase student learning?: A meta-analysis. Mich. J. Community Serv. Learn. 2012, 18, 56-61.

35. Beatty, S.H.; Meadows, K.N.; SwamiNathan, R.; Mulvihill, C. The effects of an alternative spring break program on student development. J. High. Educ. Outreach Engagem. 2016, 20, 90-119.

36. Niehaus, E. Building momentum in student engagement: Alternative breaks and students' social justice and diversity orientation. J. Coll. Stud. Dev. 2017, 58, 58-70. [CrossRef]

37. Jones, S.R.; Rowan-Kenyon, H.T.; Ireland SM, Y.; Niehaus, E.; Skendall, K.C. The meaning students make as participants in short-term immersion programs. J. Coll. Stud. Dev. 2012, 53, 201-220. [CrossRef]

38. Bowen, G.A. Fostering college students' civic commitment through alternative breaks. J. Civ. Commit. 2011, 16, 1-13.

39. Niehaus, E.; Kurotsuchi Inkelas, K. Exploring the role of alternative service break programs in students' career development. J. Stud. Aff. Res. Pract. 2015, 52, 134-148.

40. Association of American Colleges and Universities. "Civic Engagement VALUE Rubric" 2009. Available online: https://www.aacu.org/civic-engagement-value-rubric (accessed on 30 May 2019).

41. Vogelgesang, L.J.; Astin, A.W. Comparing the effects of community service and service-learning. Mich. J. Community Serv. Learn. 2000, 7, 25-34.

42. Stewart, D.L.; Nicolazzo, Z. High impact of [whiteness] on trans* students in postsecondary education. Equity Excell. Educ. 2018, 51, 132-145. [CrossRef]

43. Killermann, S. What Does the Asterisk in "Trans" Stand for? Available online: https:// www.itspronouncedmetrosexual.com/2012/05/what-does-the-asterisk-in-trans-stand-for/ (accessed on 26 August 2019).

44. Orr, D. The (missing) politics of environmental education. Sustainability 2019, 12, 53-59. [CrossRef]

45. Hanstedt, P. Creating Wicked Students: Designing Courses for a Complex World; Stylus: Stirling, VA, USA, 2018.

(C) 2019 by the authors. Licensee MDPI, Basel, Switzerland. This article is an open access article distributed under the terms and conditions of the Creative Commons Attribution (CC BY) license (http://creativecommons.org/licenses/by/4.0/). 